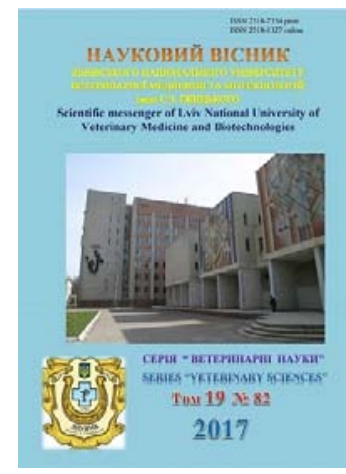

Науковий вісник Львівського національного університету ветеринарної медицини та біотехнологій імені С.З. Гжицького

Scientific Messenger of Lviv National University of Veterinary Medicine and Biotechnologies

doi:10.15421/nvlvet8222

ISSN 2518-7554 print

ISSN 2518-1327 online

$\underline{\text { http://nvlvet.com.ua/ }}$

УДК 619: 636.2: 591. 366

\title{
Вплив уведеного сухостійним коровам трутенату на вміст цинку, купруму і мангану в крові, материнській частині плаценти і перебіг отелення
}

\author{
C.В. Круть \\ d.fvm@znau.edu.ua
}

Житомирський національний агроекологічний університет,
Старий Бульвар 7, Житомир, 10002, Україна;

\begin{abstract}
У досліді, проведеному на 98 коровах, з яких сформовано 3 групи корів по 6 у кожній, з'ясували вплив уведеного їм під час сухостою трутенату на вміст в крові та карункулах материнської частини плаценти Цинку, Купруму і Мангану та перебіг третьої стадії отелення. Коровам контрольних груп: першої - за фізіологічного перебігу третьої стадії отелення, і третьої - за затримання посліду трутенат не вводили, а другій - вводили трутенат з розрахунку 7 мл на 100 кг ваги триразово з проміжком 7 діб. У всіх корів у першу стадію отелення відбирали кров з яремної вени, а через 30-45 хв після народження телят екстерпували по 2 карункули, у яких визначали концентрацію досліджуваних мінеральних речовин. Установлено коливання в крові та в карункулах рівня мінералів за різного перебігу третьої стадії отелення. Перебіг стадій отелення в фізіологічних рамках часу відбувався за наявності в крові Zn-від 130,1 до 142,8, Сu-від 90,1 до 108,2, Мn-від 3,5 до 3,8 мкг\%. За кониентрації в крові корів Zn 130,8, Cu-100,8, Mn - 3,5; Cu - 142,8 - 103,7 - 3,8 ma 141,9-108,2 i 3,7 мкг\% відповідно послідова стадія тривала в середньому 10,5 години, а за-134,5, 90,8 та 3,7 мкг\%, 130,1- 93,2 та 3,6; 131,3-90,1 та 3,8 мкг\% відповідно - 16,5 години. Концентрація Zn в карункулах корів за патології третьої стадії отелення вища, порівняно з коровами другої (дослідної) групи і першої (контрольної) групи, Си - нижча, порівняно з першою і другою контрольними, Мn - нижча щуодо обох контрольних груп.

Фізіологічне отелення перебігало на тлі різної конщентрачії в карункулах материнської частини плаценти Цинку (61,45 \pm 1,34 мікромоль/л), Купруму $(0,73 \pm 0,1$ мікромоль/л) і Мангану $(213,3 \pm 2,70$ мікромоль/л).
\end{abstract}

Ключові слова: отелення, Цинк, Купрум, Манган, плащента, кров, карункул, послід, корови, лікування.

\section{Влияние введеного сухостойным коровам трутената на содержание цинка, купрума и мангана в крови, материнской части плаценты и течение отела}

\author{
С.И. Круть \\ d.fvm@znau.edu.ua
}

Житомирский национальный агроэкологический университет,
Старый Бульвар 7, Житомир, 10002, Украина;

\begin{abstract}
В опыте, проведенном на 98 коровах, из которых сформировано 3 группы коров по 6 голов в каждой, исследовано влияние им введенного трутената на содержание в карункулах материнской части плаценты и течение отела $\mathrm{Zn}$, Cи $i \mathrm{Mn}$. Коровам контрольных групп: первой - при течении физиологического отела и третьей, при задержании последа препарат не вводили, второй - три раза с промежутком 7 дней подкожно инъецировали трутенат в дозе 7 мл на 100 кг веса. У всех коров спустя 30-45 минут после рождения теленка экстерпировали по 2 карункула, в которых определили содержание минералов.Установлено колебание в карункулах уровня исследованных веществ в зависимости от течения третьей стадии отела. Концентрация Zn в карункулах коров при задержании последа высшая, чем у коров второй (опытной) и первой контрольной, Си - ниже по сравнению с первой и второй контрольной, Мn - ниже относительно обеих контрольных.
\end{abstract}

Citation:

Kruty, S.I. (2017). The influence of introduced Trutenat to dry cows on contents of Zincum, Cuprum and Mangan in carunculs of the placenta maternal part and the course of calving. Scientific Messenger LNUVMB, 19(82), 105-109. 
Физиологический отел протекает при различной концентрации в карункулах материнской части плаценты Цинка

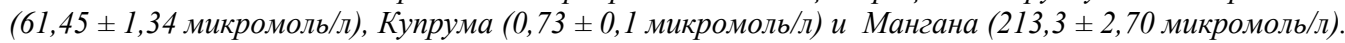

Ключевые слова: отел, цинк, купрум, манган, плачента, кровь.

\title{
The influence of introduced Trutenat to dry cows on contents of Zincum, Cuprum and Mangan in carunculs of the placenta maternal part and the course of calving
}

\author{
S.I. Kruty \\ d.fvm@znau.edu.ua \\ Zhytomyr National Agroecological University, \\ Old Bulvar 7, Zhytomyr, 10002, Ukraine;
}

\begin{abstract}
In the experiment carried out on three groups of dry cows 6 goals in each, the influence of introducing of Trutenat to them on the content of Zincum, Cuprum and Mangan in carunculs of the placenta maternal part and the course of calving researched. The drug is not introduced to cows of control groups, the first group with course of physiological calving and the third at detention of the placenta, and the second group was injected three times at intervals of 7 days, were injected subcutaneously Trutenat in a dose of $7 \mathrm{ml} / 100 \mathrm{~kg}$ of body weight. At all cows throughout 30-45 minutes after birth of the calf we exterpited 2 caruncles, in which we determined the mineral content. The level fluctuation of the test substances in carunculs depending on the current third stage of calving set. The concentration of Zincum in carunculs of cows during the detention of the placenta is higher than in cows of the second (experimental) and the first (control) groups, and Cuprum is lower compared to the first and the second control group, Mangan - below relative to both control groups.The physiological calving courses with different concentration of $\mathrm{Zn}$ (61.45 \pm $1.34 \mu \mathrm{mol} / \mathrm{l}), \mathrm{Cu}(0.73 \pm 0.1 \mu \mathrm{mol} / \mathrm{l})$ and $\mathrm{Mn}(213.3 \pm 2.7 \mu \mathrm{mol} / \mathrm{l})$ in carunculs of the placenta maternal part. The second stage of calving of all cows was within the physiological framework without rendering assistance, ranged from 57 to 85 minutes and amounted 67.5 minutes to an average.Depending on the duration of the third stage of calving we determined the relationship of the studied mineral substances between their levels in blood and maternal parts of the placenta. On the pathology of the third stage of calving in cows blood in the first stage the level of Zinc amounted to $134.15 \mu \mathrm{g} \%$, Cuprum-90.8 $\mu \mathrm{g} \%$, Mangan-to $3.7 \mu \mathrm{g}$. Separation of the placenta lasted longer for 20-22 hours.
\end{abstract}

Key words: calving, Zincum, Cuprum, Mangan, detention of the placenta. Caruncul

\section{Вступ}

Отелення як складний фізіологічний процес залежить від багатьох чинників, серед яких важливе значення має рівень в крові, материнській і фетальній частинах плаценти мінеральних речовин. Із 92 існуючих у природі мінеральних речовин в організмі людей і тварин виявлено 26 (Rusak and Chala, 2016).

Окремі автори виділяють фактори і причини перебігу родів, що зумовлені перебудовою функцій всіх систем організму під кінець вагітності. Особливе значення, вважають автори, відіграють біоенергетичні фактори, що визначають готовність матки наприкінці вагітності до посиленого скорочення. В організмі максимально синтезується скоротливий білок актиномізин, глікоген, АТФ, електроліти, $\mathrm{Ca}, \mathrm{Na}, \mathrm{K}$, мікроелементи, Co, Fe, Zn тощо (Kalinovsky et al., 2009: Zakharchenko, 2012).

Склад крові корів у сухостійний період та під час отелення частково відображені у працях Афанасієвої Л.П. (Afanasyeva and Kalinovsky, 2007), 3axapiна B.B. (Zakharin et al., 2007), Грищука Г.П. (Grischuk et al., 2007), Захарченка B.A. (Zakharchenko, 2012) та інших. За їх даними, протягом перебігу тільності рівень $\mathrm{Cu}, \mathrm{Zn}$ і Mn у крові корів та в плаценті коливається в значних межах. Грищук Г.П. (2014) та Захарченко В.А. (2013) встановили, що перебіг фізіологічного отелення при патології третьої стадії отелення відбувається за різної концентрації в крові та в плаценті макро- і мікроелементів. За їх даними важливе значення мають макро- і мікроелементи як складники багатьох біологічно активних речовин.

В останні тижні сухостійного періоду, 3 наближенням отелення і появою його передвісників, зміни в організмі досягають найвищого розвитку. За таких умов інформативного клінічного значення набуває оцінка стану корів за вмістом в крові та плаценті мінеральних речовин.

Мета $i$ завдання роботи - з'ясувати вплив уведеного сухостійним коровам тканинного препарату «Трутенат», виготовленого 3 личинок 5-7-денних трутнів, на вміст в крові та карункулах у першу стадію отелення Zn, Cu i Mn та перебіг отелення.

\section{Матеріал і методи дослідження}

Дослідження виконані в зимово-весняний період на 98 коровах чорно-рябої української молочної породи.

Формування груп корів проводили шляхом відбоpy iз 98 голів, на яких досліджували вплив трутенату на перебіг отелення. У всіх групах було по 6 корів: корови першої і третьої групи були контрольними, їм трутенат не вводили. У корів першої і другої групи отелення перебігало з відділенням посліду до 6 годин після народження телят, у третьої групи - понад 18 годин. До другої дослідної групи, увійшли корови, яким протягом сухостійного періоду тричі з інтервалом 7 діб уводили трутенат з розрахунку 7 мл на 100 кг живої маси. В усіх корів у першу стадію отелення відбирали проби венозної крові для лаборатор- 
ного дослідження, протягом 30 хвилин після виведення плода проводили екстирпацію карункулів. Виділення посліду протягом 6 годин після народження теляти вважали нормою і лікування не застосовували, а 36 до 18 - теж нормою, але застосовували лікування. Вміст Купруму, Цинку і Мангану в крові і карункулах визначали методом атомно-абсорційної спектрофотометрії згідно з ГОСТом 301780-96I297 (Grischuk et al., 2007; Grishchuk and Revunets, 2008; Grishchuk, 2013; Rusak and Chala, 2016).

\section{Результати та їх обговорення}

Нами встановлено, що в крові корів у першу стадію отелення концентрація Zn найвища і становила 142,8 мкг\%, Cu дещо нижча - 103,7 мкг\%, а Mn найнижча і дорівнювала 3,8 мкг\% (табл. 1).

Біологічна роль в організмі Zn відома як кофермента в складі багатьох ферментів, активатора ферментів і гонадотропних та статевих гормонів, у гальмуванні згортання крові (Rusak and Chala, 2016).
Вміст Zn в сироватці крові великої рогатої худоби становить 100-150 мкг/100 мл, або 15,423,0 мкмоль/л, $\mathrm{Cu}-80-120$ мкг/100 мл або 12,6-18,9 мкмоль/л, $\mathrm{Mn}$ - 5,4-5,95 ммоль/л, 2 мкг/100 мл 1,3 - в сироватці (Rusak and Chala, 2016).

Отримані нами показники щодо концентрації Zn в крові корів за фізіологічного і патологічного отелення не узгоджуються 3 даними В.А. Захарченка i Г.П. Грищука, згідно якими зменшення концентрації $\mathrm{Zn}$ в крові корів спостерігається за затримання посліду.

Перебіг другої стадії отелення у всіх корів відбувався в фізіологічних рамках без надання сторонньої допомоги, коливався в межах від 57 до 85 хв і становив в середньому 67,5 хв.

Послідовна стадія тривала від 8,5 до 22 годин і становила (М) 12,8 години (табл. 1).

Отже, в корів за фізіологічного перебігу отелення виведення плодів тривало в середньому 67,15 хвилини, відділення і вигнання посліду $-12,8$ години.

Таблиия 1

Вміст МЕ в крові корів під час отелення

\begin{tabular}{|c|c|c|c|c|c|}
\hline \multirow{2}{*}{ № } & \multicolumn{3}{|c|}{ Перша стадія отелення, вміст мікроелементів } & Друга стадія & Третя стадія \\
\cline { 2 - 6 } & Zn мкг\% & Си мкг\% & Мп мкг\% & Тривалість хвилин & Тривавлість годин \\
\hline 1 & 130,5 & 102,5 & 3,5 & 65 & 12 \\
\hline 2 & 134,5 & 90,8 & $3 / 7$ & 70 & 20 \\
\hline 3 & 130,1 & 93,2 & 3,6 & 60 & 22 \\
\hline 4 & 130,8 & 100,8 & 3,5 & 65 & 9 \\
\hline 5 & 131,3 & 90,1 & 3,8 & 68 & 12 \\
\hline 6 & 132,7 & 102,5 & 3,7 & 70 & 8,5 \\
\hline 7 & 142,8 & 103,7 & 3,8 & 85 & 9,5 \\
\hline 8 & 141,9 & 108,2 & 3,7 & 57 & 10 \\
\hline
\end{tabular}

Примітка: перебіг другої стадії отелення до 4 годин та третьої стадії до 6 вважали за норму

Таблиия 2

Вміст Zn, Cu i Mn в карункулах, $\mathrm{n}=18, \mathrm{M} \pm \mathrm{m}$

\begin{tabular}{|c|c|c|c|}
\hline Групи, $\mathrm{n}$ & $\mathrm{Zn}$, мікромоль/л & Сu, мікромоль/л & Mn, мікромоль/л \\
\hline перша, контроль $\mathrm{n}=6$, & $61,45 \pm 1,34$ & $0,73 \pm 0,1$ & $213,30 \pm 2,70$ \\
\hline друга, дослід $\mathrm{n}=6$, трутенат & $61,30 \pm 2,82$ & $0,65 \pm 0,02$ & $212,30 \pm 2,30$ \\
\hline третя, контроль $\mathrm{n}=6$ & $64,10 \pm 1,09$ & $0,72 \pm 0,01$ & $216,60 \pm 2,40$ \\
\hline
\end{tabular}

Примітка: корови 1 групи - фізіологічний перебіг отелення, їм нічого не вводили, контроль, корови 2 групи дослідної, фізіологічний перебіг отелення, їм уводили трутенат, корови 3 групи - затримання посліду, контроль, їм не вводили трутенат

Залежно від тривалості 3 стадії отелення корів визначали взаємозв'язок досліджуваних мінеральних речовин між їх рівнем у крові та материнській частині плаценти (табл.1).

За патології 3 стадії отелення (табл. 1) в крові корів $(22,3)$ у першу стадію рівень $\mathrm{Zn}$ становив (M) 134,5 мкг\%, Cu 90,8 мкг\%, Mn 3,7 мкг\%, і відділення посліду тривало найдовше - протягом 20-22 години

Отримані результати є доказовими щодо впливу на перебіг отелення досліджуваних мінеральних речовин, оскільки за вищої концентрації Zn (142,8; 141,9; $132,7 ; 130,8 ; 130,5 ; 131,3)$ i $\mathrm{Cu}(102,5 ; 100,8 ; 102,5$; $103,7 ; 108,2)$ в крові корів у першу стадію отелення послідова стадія була короткою і тривала (M) 10,5 годин, а в решти корів - 16,5 години. Концентрація $\mathrm{Cu}$ в крові корів за фізіологічного перебігу оте- лення вища (100,8 мг\%, 102,5 мг\%, 103,7 мг\%), ніж при затриманні посліду (90,80 мг\%, 92,3 мг\%).

Можемо припустити, що вищий рівень $\mathrm{Zn}$ і $\mathrm{Cu}$ в крові корів у першу стадію отелення впливає на перебіг фізіологічних процесів $у$ всьому організмі, бо друга стадія отелення, у якій задіяні не лише м'язи матки, але й скелету, у них коротша і становить 10,5 хвилин (табл. 1).

Рівень цинку, що міститься у всіх тканинах і його біологічне значення проявляється як активатора ферментів та впливом на всі ланки метаболізму. Дефіцит $\mathrm{Zn}$ в організмі супроводжуються порушенням перебігу статевого циклу і в багатьох випадках може бути причиною аборту (Rusak and Chala, 2016).

Необхідно також зважати на те, що карункули, як материнська частина плаценти, виконують функцію 
плацентарного бар'єру з боку матері. Залежно від стану організму та кровообігу в матці під час отелення, в материнській частині плацентарного бар'єру накопичується різна кількість складників крові мінеральних речовин.

При затриманні посліду концентрація Zn в карункулах, порівняно з фізіологічним перебігом отелення, як у досліді, так і в контролі найвища (табл. 2) і становить $64,10 \pm 1,09$ мікромоль/л.

Привертає увагу те, що $\mathrm{Zn}$ в організмі затримує згортання крові (Rusak and Chala, 2016). Відомо, що однією $з$ основних причин затримання навколоплідних оболонок у корів $є$ гальмування згортання крові в мікроциркуляторному судинному руслі материнської частини плаценти (Kalinovsky et al., 2009). Результати наших досліджень щодо порівняно вищої концентраціï $\mathrm{Zn}$ в материнській частині плаценти підтверджують це обгрунтування як однієї з причин патології третьої стадії отелення.

Купрум поряд з багатьма притаманними йому функціями в організмі має важливе значення у відтворенні. Основна частина $\mathrm{Cu}$ входить до складу білка гострої фази запалення церулоплазміну. Засвоєнню $\mathrm{Cu}$ сприяє $\mathrm{Zn}$, але надлишок його впливає токсично на організм (Grischuk et al., 2007; Zakharin et al., 2007; Grishchuk, 2013).

Наявну концентрацію $\mathrm{Cu}$ при затриманні посліду $(0,72 \pm 0,01$ мікромоль/л) можна пояснити і обгрунтувати тим, що при його оперативному відділенні в рамках часу, вказаного вище, воно не ускладнюється запальним процесом.

Вміст Mn в тілі корів залежить від їхньої ваги і в середньому становить 240 г, депонується найбільше в кістках та в м'язах, менше в крові та в тканинній рідині. Він бере участь при синтезі білкового комплексу, необхідного для скорочення м'язів, впливає на функцію ЦНС і активує холінестеразу, що стимулює розпад ацетилхоліну. В результаті таких процесів гальмується збудливість нервових закінчень і м'язи розслабляються. Рівень загального Mn у сироватці крові всіх тварин коливався в межах від 3,8 до 3,5 мг/100 мл.

За даними Захарченка В.А. (2010), рівень Mn в фетальній частині плаценти за фізіологічного перебігу отелення і при патології третьої стадії отелення не змінюється, a Zn, при схильності до затримання посліду, вищий на 3,5\%. Обгрунтування, зроблене автором, треба приймати до уваги, але такий рівень досліджуваних мінералів у материнській частині плаценти, вважаємо, має й іншу інтерпретацію. Тут важливо оцінити їх уміст за врахування материнської частини плаценти як плацентарного бар'єру.

За даними Л.П. Афанасієвої (Afanasyeva and Kalinovsky, 2007), материнська і фетальна частини плаценти як складника плацентарного бар'єру, мають різну здатність затримувати і пропускати мінеральні речовини протягом тільності в напрямі мати - плід.

Г.П. Грищук (2013) вказує, що перебіг третьої стадії отелення в фізіологічних межах відбувається за нижчої концентрації в карункулах материнської частини плаценти $\mathrm{Cu}$ i Zn та вищої Mn. Результати наших досліджень погоджуються $з$ установленими автором показниками лише в частині рівня в карункулах Zn i $\mathrm{Cu}$ за уведення трутенату (табл. 2).

Зважаючи на фізіологічне значення в організмі обох мінералів протягом тільності як для функціонування органів всіх систем корови, так і формування, розвитку і росту плода, про їх участь у перебігу отелення повідомлення обмежені.

Проте, як показують наші дослідження, наявність $\mathrm{Zn}$ i $\mathrm{Cu}$ в різних концентраціях в крові корів під час перебігу отелення, свідчить про їх важливу функцію. Зокрема, про це $є$ підстава стверджувати, зважаючи на те, що за фізіологічного періоду отелення їх концентрація вища.

Вищий рівень Mn у карункулах при затриманні посліду певною мірою залежить від статевих гормонів та біохімічних процесів у гіпофізі. Не виключено, що вища концентрація Mn в карункулах є однією з ланок в ланцюгу гіпофіз-яєчники-матка виникнення і перебігу отелення та причини затримання посліду, зокрема збереження і функціонування жовтого тіла тільності. Уміст Mn, незважаючи на його низьку концентрацію в тканинах корів, має важливе біологічне значення насамперед для нормального функціонування статевих органів (Rusak and Chala, 2016). Привертає увагу біологічна роль $\mathrm{Mn}$, що проявляється в стимулюванні глюконеогенезу та підтриманні рівня глюкози в крові, особливо, що важливо, під час перебігу першої і другої стадій отелення, коли максимально проявляється скорочувальна функція не лише м'язів матки, а й усього організму. Зменшення концентрації в крові корів у першу стадію отелення Mn пов'язане, очевидно, з перебігом другої стадії, тривалість якої коротша.

Порівняно з іншими органами $\mathrm{Zn}$ під час тільності найбільше накопичується в яєчниках та матці. Встановлено його участь у процесах синтезу холестерину і статевих гормонів як їх похідних. За дефіциту Zn сповільнюється статеве дозрівання, гальмується прояв стадій статевого циклу, знижується запліднення, виникають аборти. Виявлена нами концентрація Zn в крові корів за затримання посліду, порівняно з фізіологічним перебігом третьої стадії отелення, вважаємо, пов'язана зі зниженням в ній $\mathrm{Cu}$ і зумовлена часом відбору крові. У сироватці крові за фізіологічного (3,5 мг\%) і патологічного перебігу отелення (3,7 мг\%) концентрація Mn вірогідно не відрізняється, що, очевидно, не впливає на їх тривалість

\section{Висновки}

1. Фізіологічне отелення перебігає на тлі різної концентрації в крові $\mathrm{Zn}$ - від 130,1 до 142,8 мкг\%, Cu - від 90,1 до 108,2 мкг\%, Mn від 3,5 до 3,8 мкг\%, відповідно в карункулах материнської частини плаценти $\mathrm{Zn}(64,10 \pm 1,09$ мікромоль/л), $\mathrm{Cu}(0,72 \pm$ 0,01 мікромоль/л) і Mn (213,3 $\pm 2,70$ мікромоль/л).

2. Третя стадія отелення при відділенні посліду, що тривало від 6 до 18 годин, перебігала за вищого рівня в карункулах материнської частини плаценти Zn $(64,10 \pm 1,09$ мікромоль/л) та $\operatorname{Mn}(216,60 \pm 2,40$ мікромоль/л).

3. Триразове підшкірне введення сухостійним коровам тканинного препарату трутенат з розрахунку 
7 мл на 100 кг живої маси проявляється зниженням, порівняно з фізіологічним $(0,73 \pm 0,10$ мікромоль/л) та патологічним $(0,72 \pm 0,01$ мікромоль/л) перебігом отелення, рівня в карункулах материнської частини плаценти $\mathrm{Cu}(0,65 \pm 0,02$ мікромоль/л).

Перспективи подальших досліджень. 3'ясувати вплив трутенату на імунний статус корів протягом тільності, отелення і післяотельного періоду.

\section{Бібліографічні посилання}

Afanasyeva, L.P., Kalinovsky, G.M. (2007). Permeability of heavy metals through the placental barrier of the cow. Bulletin of the Sumy NAU. 8(19), 5-8 (in Ukrainian).

Grischuk, G.P., Kalinovsky, G.M., Revunets, AS, Kovalchuk, Yu.V. (2007). The content of trace elements in the placenta and blood of cows. Visn. Polt agrar.akad. Poltava. 3, 36-38 (in Ukrainian).

Grishchuk, G.P., Revunets, A.C. (2008). The composition of a tissue preparation made from the uterus of various types of animals. Naukovyi Visnyk of Lviv National University of Veterinary Medicine and Biotechnology. S. Z. Gzhytsky. 10, 2(37), 58-60 (in Ukrainian).

Grishchuk, G.P. (2013). The composition of the tissue preparation made from the uterus of various species of animals. Materials of the international scientific and practical conference devoted to the 75th anniversary of the birth and the 50th anniversary of the scientific and practical activity of the Doctor of Veterinary Sci- ences, Professor G.F. Medvedev. Gorki, 172-175 (in Russian).

Zasekin, D.A. (2003). Function of the placental barrier in the migration of heavy metals from the body of the cow from mother to fetus. Veterinary Medicine of Ukraine. 8, 40-41 (in Ukrainian).

Zakharin, V.V., Kalinovsky, G. M., Ivanovets, A.S. (2007). The course of calving in the heifers and postoperative period in primary cows. Bulletin of the State Duma. 2(19), 18-24 (in Ukrainian).

Zakharchenko, V.A. (2012). Detentions of litter from cows: etiology, pathogenesis, treatment and prophylaxis: author's abstract. on dis for obtaining sciences. Degree Candidate vet Sciences: special 16.00.07 «Veterinary obstetrics». Sumy (in Ukrainian).

Rusak, V.S., Chala, I.V. (2016). Clinical evaluation of biochemical, morphological indices of blood and urine of animals. Textbook. Zhytomyr: «Polissya» (in Ukrainian).

Kalinovsky, G.M., Revunets, A.S., Grischuk, G.P. (2009). Hormonal and microelement composition of the tissue preparation of fetoplacenta, made from the uterus of various species of animals. Scientific. Bulletin of the National University of Bioresources and Nature Management. Kyiv. 136, 76-81 (in Ukrainian).

Received 2.10.2017

Received in revised form 30.10 .2017 Accepted 2.11.2017 